\title{
Pengaruh Aromaterapi Terhadap Kualitas Tidur, Kualitas Hidup, Kelelahan dan Kecemasan Pada Pasien Diabetes Melitus
}

\author{
Ida Faridah $^{1^{*}}$,Yati Afiyanti ${ }^{2}$, Mega Ariska $^{3}$ \\ ${ }^{1,3}$ STIKes Yatsi Tangerang, ${ }^{2}$ Universitas Indonesia Fakultas Keperawatan \\ *Email: ida.farida72@gmail.com
}

\begin{abstract}
Background: Diabetes mellitus is an incurable disease but can be controlled by controlling blood sugar levels and improving sleep quality and quality of life in people with diabetes. The prevalence of diabetes mellitus in Banten province has increased in 2013 by 1.3\%, while in 2018 it was 2.2\%. The purpose of this study is to determine the effectiveness of aromatherapy in patients with diabetes mellitus. Methods: The method used to analyze data is Systematic Literature Review. Search for articles using google scholar database, PubMed, Research Gate, and Elsevier and get eight relevant articles and analyzed using the simplified thematic approach. The article selection process is done using a PRISMA flow diagram. Results: lavender aromatherapy, bitter orange and sandalwood or sandalwood significantly affect changes in sleep quality, quality of life, anxiety and fatigue in patients with type 1 and 2 diabetes mellitus with a combination of massage therapy and foot exercises. Thus, it can be concluded that aromatherapy is effective on sleep quality, quality of life, anxiety and fatigue in patients with type 1 and 2 diabetes mellitus.Conclusion: Therefore, the use of aromatherapy can be recommended as a non-pharmacological intervention that can affect sleep quality in patients with type 2.
\end{abstract}

Keywords: anxiety, aromatherapy, diabetes mellitus, fatigue, sleep quality, quality of life

\section{PENDAHULUAN}

Diabetes merupakan penyakit kronik yang dapat menimbulkan kerusakan serius pada jantung, pembuluh darah, mata, ginjal, serta saraf dan terjadi saat tubuh resistensi terhadap insulin ditandai dengan peningkatan kadar gula darah (WHO, 2018). Berdasarkan data American Diabetes Association (ADA) diperkirakan 30,3 juta orang dari semua jenis usia atau sebanyak $9,4 \%$ dari populasi Amerika Serikat menderita Diabetes. Sebanyak 30,2 juta orang dewasa dengan usia 18 tahun atau lebih sebanyak $12,2 \%$, dan 7,2 juta orang dengan presentase $23,8 \%$ tidak mengetahui atau tidak melaporkan penyakit diabetes. Terjadi peningkatan presentase pada pasien diabetes yang berusia 65 tahun yaitu sebanyak 25,2\% (Care, 2017).

Pada tahun 2019 negara dengan jumlah penduduk tertinggi penderita diabetes melitus kelompok usia $20-79$ tahun adalah Cina (54,5 juta), Amerika Serikat (37,4 juta) dan Indonesia $(29,1$ juta). Diperkirakan 19,4 juta orang dewasa berusia 20 - 79 tahun menderita diabetes melitus di wilayah Afrika dengan tingkat penyebaran penyakit $3,9 \%$. Jumlah orang dewasa berusia 20 79 tahun yang menderita diabetes melitus di Eropa diperkirakan 59,3 juta. Di Asia Tenggara tahun 2019 menunjukkan bahwa $8,8 \%$ dari populasi dewasa berusia 20 - 79 tahun menderita diabetes.Di perkirakan pada tahun $2019,9,6 \%$ orang dewasa berusia 20-79 tahun terkena diabetes di kawasan Asia Pasifik dengan jumlah 162,6 juta orang (Atlas, 2019).

Berdasarkan data dari Riskesdas pada tahun 2018 prevalensi diabetes melitus berdasarkan diagnosis dokter pada penduduk umur $\geq 15$ tahun menurut provinsi tahun 2018 mengalami peningkatan pada tahun 2013 sebanyak 
6,9\% sedangkan di tahun 2018 sebanyak $8,5 \%$. Prevalensi diabetes melitus berdasarkan diagnosis dokter dan usia $\geq$ 15 tahun yang terendah terdapat di Provinsi NTT, yaitu sebesar 0,9\%, sedangkan prevalensi tertinggi di Provinsi DKI Jakarta sebesar 3,4\%. Prevalensi diabetes melitus di Provinsi Banten mengalami peningkatan pada tahun 2013 sebanyak $1,3 \%$ sedangkan tahun 2018 sebanyak 2.2\% (Riskesdas, 2018).

Diabetes adalah penyakit kronis yang tidak dapat disembuhkan yang disebabkan oleh kurangnya insulin tipe 1 ataupun tipe 2, kedua jenis ini berhubungan dengan komplikasi jangka pendek dan jangka panjang yang dapat mempengaruhi kualitas hidup individu dan sering menimbulkan rasa takut serta ketidakberdayaan. Selain itu, diabetes tipe 2 adalah penyakit "diam" yaitu penyakit dan komplikasinya sering terjadi tanpa tanda dan gejala yang jelas, yang membuat penderita diabetes sulit menerima keadaannya. Berdasarkan dampak yang terjadi pada kualitas hidup pasien yang memiliki penyakit diabetes mellitus pada berbagai keadaan misalnya keadaan fisik, psikologis, sosial dan lingkungan, sebagian besar penderita mempunyai pengaruh negatif terhadap kualitas hidup baik yang mengalami komplikasi maupun tidak hal ini diyakini karna penyakit diabetes susah untuk disembuhkan. Seseorang yang memiliki kondisi kualitas hidup yang kurang baik akan semakin memperburuk kondisi suatu penyakit, dan begitupun sebaliknya (Hudatul Umam et al., 2020)

Faktanya diabetes mempengaruhi kehidupan salah satuya adalah luka gangren yang dapat memperburuk kualitas hidup. Setiap 15 detik seseorang meninggal dengan presentase $46,5 \%$ akibat diabetes kronik pada orang dewasa dan tidak terdiagnosis (Aikaterini, Athanasia, \& Andreas, 2017). Kualitas hidup dapat mempengaruhi respon terhadap terapi maka dari itu kualitas hidup pada pasien diabetes sangat penting (Meldy Tursina et al., 2019).

Salah satu problem umum lainnya pada penderita diabetes sebanyak 50\% pasien diabetes dengan Restless Leg Syndrome memiliki kualitas tidur yang buruk (Yu \& Chiou, 2018). Selain itu sleep apnea lebih sering terjadi pada penderita diabetes yang hubungannya sangat erat dengan obesitas. Pada penderita diabetes gangguan tidur dapat disebabkan dari berbagai faktor yang dapat mengakibatkan insomnia pada penderita diabetes, termasuk ketidaknyamanan atau rasa sakit yang berkaitan dengan neuropati perifer, sindrom kegelisahan kaki, gerakan anggota tubuh periodik, terjadi perubahan yang cepat pada glukosa darah pada malam hari sehingga menyebabkan hipoglikemia, gejala hiperglikemia, nokturia, dan depresi yang berkaitan (Khandelwai et al., 2017)

Tidur adalah periode istirahat fisik dan mental sebagai kebutuhan yang mutlak dibutuhkan manusia, tidur sangat penting untuk kesehatan dan kualitas hidup.Tetapi, gangguan tidur dan lingkungan yang tidak kondusif serta gangguan afektifdapat mengganggu kualitas tidur. Kebutuhan tidur seseorang berbeda - beda, dan berubah - ubah sepanjang siklus kehidupan. Rata - rata jumlah jam tidur pada usia dewasa yaitu 7 - 8 jam setiap malam. Namun, lama kualitas tidur yang disarankan berkurang seiring dengan bertambahnya usia, mereka seringkali kurang tidur dan cenderung tidak menghabiskan lebih 
banyak waktu dalam tahap tidur yang pulas dan tenang. Tidur kurang dari 5 jam dapat meningkatkan risiko kematian hingga $15 \%$, selain itu tidur kurang dari 5 jam juga dikaitkan dengan intoleransi glukosa dan resistensi insulin (Barakat et al., 2019).

Kualitas tidur dapat dipengaruhi oleh beberapa faktor yaitu keadaan fisik, stres psikologis, obat - obatan, latihan dan kelelahan, nutrisi dan asupan kalori, lingkungan dan motivasi. Beberapa penelitian menjelaskan bahwa durasi tidur yang sangat pendek (5 jam/malam) atau sangat panjang ( 9 jam/malam) dapat meningkatkan risiko diabetes, hasil penelitian memperlihatkan bahwa kualitas tidur yang buruk dapat mempengaruhi metabolisme glukosa, mengurangi sensitivitas insulin dan meningkatkan resistensi insulin(Lin et al., 2016).

Dalam mengurangi kecemasan, benzodiazepin sering digunakan dengan resep dokter dan dapat menghasilkan efek samping seperti mual, muntah dan kebiasaan minum obat. Salah satu metode yang dapat digunakan dalam terapi non farmakologi yaitu aromaterapi (Sharifi et al., 2017).

Aromaterapi saat ini menjadi salah satu terapi komplomenter yang tersedia dan banyak digunakan dalam praktik klinis. Terapi ini didefinisikan sebagai penggunaan minyak esensial murni dari tanaman - tanaman aromatik untuk meringankan masalah kesehatan dan meningkatkan mutu kehidupan(Gok Metin et al., 2017).

Dalam penelitian ( $\mathrm{Yu} \&$ Chiou, 2018), 1\% minyak esensial aromaterapi lavender diteteskan pada bagian sisi kanan dan kiri bantal selama 6 minggu. Dengan rata - rata usia responden adalah
52,2 tahun $38,6 \%$ pada laki - laki dan $61,4 \%$ pada perempuan dan $61,4 \%$ pasien dengan nokturia bahwa hasil pemberian aromaterapi terhadap kualitas tidur pada minggu ke 6 setelah intervensi terdapat perbedaan signifikan sebelum dan sesudah diberikan aromaterapi lavender dengan rata - rata waktu tidur responden meningkat dari 6 jam 15 menit menjadi 7 jam 55 menit.

Menurut hasil penelitian dari (Nasiri Lari et al., 2020) kelompok intervensi diberikan aromaterapi lavender yang dihirup dengan tiga tetes minyak esensial lavender pada kain linen (dua lapisan kain linen sekitar $12 * 12 \mathrm{~cm}$ ) dan menciumnya secara ritmis dan perlahan selama 5 menit pada waktu tidur. Hasil penelitian didapatkan rata - rata responden usia 56 tahun sebanyak 31 responden $59,6 \%$ terdapat hasil yang lebih baik pada kualitas tidur secara signifikan $\mathrm{P}<0,001$ pada kelompok 1 dan $\mathrm{P}<0,05$ pada kelompok 2 . Tetapi tidak ada perbedaan yang signifkan pada kadar serum gula darah puasa dan hasil antropometrik $\mathrm{P}>0,05)$.

Penelitian yang dilakukan (Hur et al., 2019) sebanyak 31 responden dengan usia 40 - 65 tahun diberikan intervensi aromaterapi lavender dan ylang - ylang $3 \%$ selama 2 minggu. Diberikan dengan cara inhalasi responden diminta memakai kalung yang berisi aromaterapi $3-6$ jam dengan kalung yang dirancang berjarak $20 \mathrm{~cm}$ dari hidung, dan melakukan pijat satu kali sehari sebelum tidur atau sebelum mandi 15 - 20 menit selama 1 minggu terdapat hasil yang signifikan pada kualitas tidur $\mathrm{P}<0.001$.

Hal ini dikarnakan minyak esensial lavender merupakan aroma minyak esensial yang populer. Minyak atsiri lavender terbuat dari tepung sari tetapi 
aromanya tidak manis seperti pada umumnya. Sebaliknya, bunga ini menghasilkan aroma yang segar dan keras dengan komposisi kamper. Minyak esensial ini memiliki konsistensi yang tipis dan biasanya uap disuling. Lavender berasal dari Bulgaria, Prancis, Ukraina dan Amerika Serikat. Aroma terapi lavender dapat digunakan sebagai anti bacterial, analgesic, anti konvulsan, anti jamur, anti septik dan vasodilator. Lavender dapat digunakan dengan cara inhalasi, diffusion, topical application dan ingestion (Ramadhan \& Zettira, 2017). Study ini bertujuan untuk mengetahui pengaruh aromaterapi terhadap kualitas tidur, kualitas hidup, kelelahan dan kecemasan pada pasien diabetes melitus.

\section{METODE PENELITIAN}

Metode yang digunakan untuk menganalisa data adalah Systematic
Literatur Review. Pencarian artikel menggunakan database google scholar, PubMed, Research Gate, dan Elsevier dan mendapatkan delapan artikel yang relevan dan dianalisis menggunakan pendekatan simplified thematic approach. Proses seleksi artikel dilakukan dengan menggunakan flow diagram PRISMA. Untuk mencari artikel penulis melakukan pencarian menggunakan bahasa Indonesia dan bahasa Inggris dengan kata kunci "Aromatherapy/ aromaterapi”, “QualitySleep/Kualitas Tidur, "Quality of Life/kualitas hidup, "Fatigue/Kelelahan",

"Anxiety/Kecemasan" dan "diabetes mellitus". Selain mengidentifikasi kata kunci, peneliti menentukan kriteria inklusi dan kriteria ekslusi sebagai syarat lain dalam melakukan pencarian sumber untuk didapat dalam tabel 1 .

Tabel 1. Kriteria Inklusi \& Kriteria Ekslusi

\begin{tabular}{|c|c|}
\hline Kriteria Inklusi & Kriteria Ekslusi \\
\hline $\begin{array}{l}\text { Population }=\text { Responden Diabetes } \\
\text { Melitus }\end{array}$ & $\begin{array}{l}\text { Responden Merupakan Pasien Cancer, } \\
\text { Pasien Hemodialis, Dan Penyakit Jantung. }\end{array}$ \\
\hline Intervention $=$ Pemberian Aromaterapi & Artikel Merupakan Sumber Sekunder \\
\hline Comparison = - & Artikel Review, Case Study \\
\hline \multicolumn{2}{|l|}{ Outcome $=$ Aromaterapi Efektif } \\
\hline $\begin{array}{l}\text { Artikel Menggunakan } \\
\text { Indonesia Dan Bahasa Inggris }\end{array}$ & \\
\hline $\begin{array}{l}\text { Artikel Merupakan Sumber Primer } \\
\text { (Primary Source) }\end{array}$ & \\
\hline $\begin{array}{l}\text { Jenis Penelitian Eksperimen, Quasy } \\
\text { Eksperimen Dan Rct }\end{array}$ & \\
\hline $\begin{array}{l}\text { Publikasi Artikel Dalam Rentang } \\
\text { Waktu } 5 \text { Tahun (2015-2020) }\end{array}$ & \\
\hline
\end{tabular}

\section{HASIL PENELITIAN}

Berikut ini adalah keterangan yang dibutuhkan dalam menentukan artikel yang digunakan sebagai kajian literatur sesuai dengan kriteria inklusi, ekslusi, database, dapat dilihat pada gambar 1 . 
Hasil pencarian artikel penelitian dengan menggunakan PRISMA flow diagram.

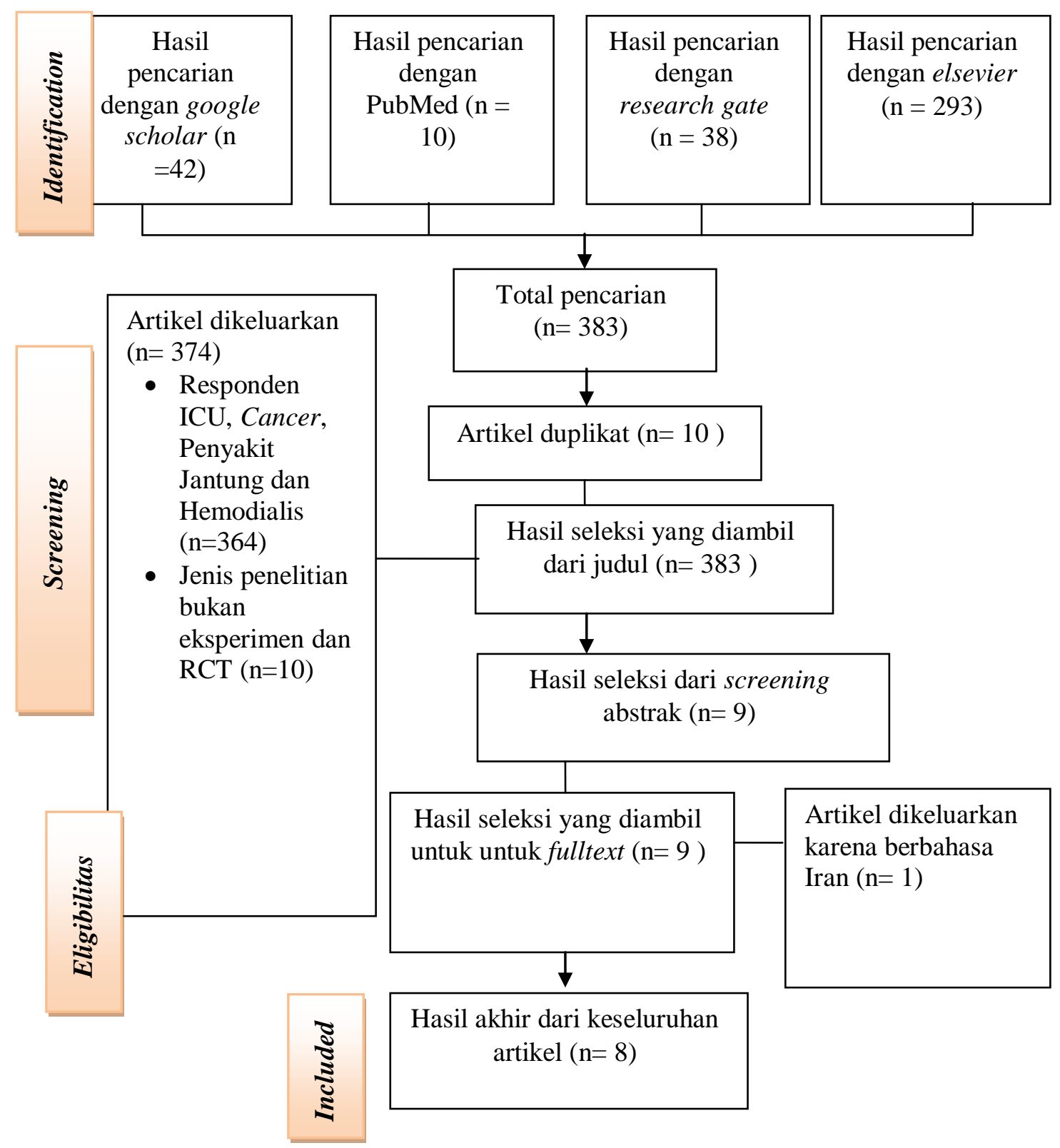

\section{Gambar 1. Modifikasi PRISMA}

Pada pencarian yang dilakukan dengan menggunakan beberapa sumber dari database, yaitu google scholar ditemukan 42 artikel, PubMed ditemukan 10 artikel, Reserch gate ditemukan 38 artikel dan elsevier ditemukan 293 artikel. Total artikel yang diperoleh pada awal pencarian sesuai dengan kata kunci yang telah ditetapkan, yaitu 383 artikel, artikel yang teridentifikasi kemudian ditemukan 10 artikel duplikat dan 
dilakukan screening ditemukan artikel yang sesuai dengan judul yaitu 9 artikel.

Selanjutnya, 374 artikel diekslusi ditemukan 364 artikel dengan responden pasien ICU, Cancer, Penyakit Jantung dan Hemodialis, lalu 10 artikel ditemukan jenis penelitian bukan eksperimen dan RCT. Adapun artikel yang dikeluarkan karena berbahasa Iran 1 artikel. Setelah itu peneliti mendapatkan 8 artikel yang layak dianalisa karena sesuai dengan topik dan tujuan penelitian dengan desain penelitian quasi eksperimen, eksperimen dan RCT. Berikut adalah hasil identifikasi tema dari artikel yang masuk dalam kriteria inklusi untuk melakukan kajian literatur.

Tabel 2. Hasil Identifikasi Tema

\begin{tabular}{|c|c|c|c|}
\hline Penulis, Tahun & Judul & $\begin{array}{c}\text { Metode Pemberian } \\
\text { dan Hasil }\end{array}$ & Tema \\
\hline - $\underset{2018)}{(\mathrm{Yu} \& \text { Chiou, }}$ & $\begin{array}{l}\text { - The Effect Of } \\
\text { Aromatherapy On } \\
\text { Sleep Quality In } \\
\text { Diabetes Patients } \\
\text { With Restless Leg } \\
\text { Syndrome In } \\
\text { Taiwan }\end{array}$ & 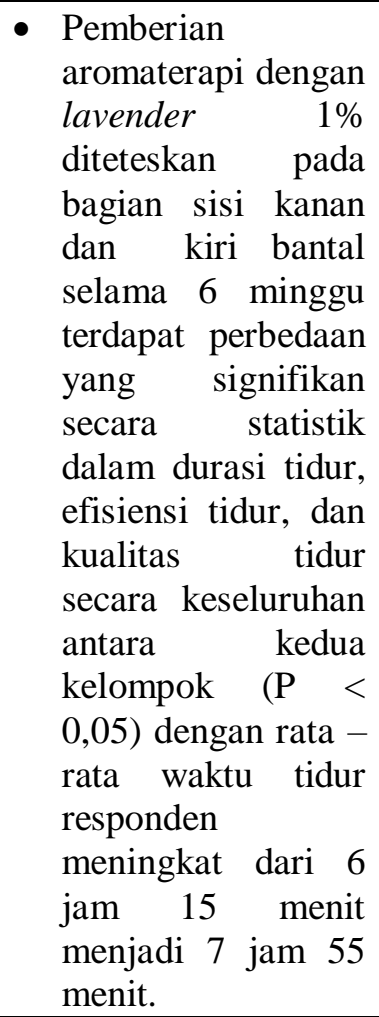 & $\begin{array}{l}\text { Terapi Aromaterapi } \\
\text { Lavender dengan } \\
\text { cara inhalasi }\end{array}$ \\
\hline $\begin{array}{l}\text { - (Wijayanti } \\
\text { al., 2019) }\end{array}$ & $\begin{array}{l}\text { Autogenic } \\
\text { Relaxation With } \\
\text { Aromatherapy } \\
\text { Cendana on The } \\
\text { Quality Sleeping In } \\
\text { Patients Diabetes } \\
\text { Mellitus Type } 2\end{array}$ & 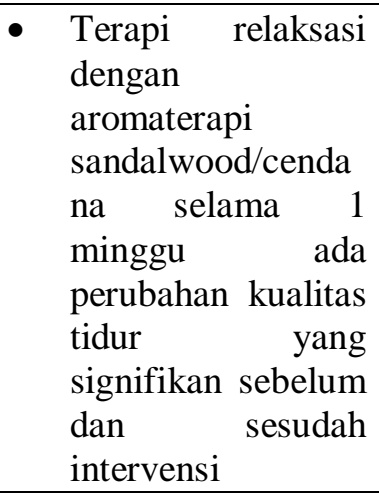 & $\begin{array}{l}\text { Terapi relaksasi } \\
\text { autogenik dengan } \\
\text { Aromaterapi } \\
\text { sandalwood/ cendana }\end{array}$ \\
\hline
\end{tabular}




\begin{tabular}{|c|c|c|c|}
\hline & & $\begin{array}{l}\text { diberikan. } \\
\text { Kelompok } \\
\text { intervensi } \\
\text { meningkatkan } \\
\text { kualitas tidur lebih } \\
\text { besar daripada } \\
\text { kelompok kontrol } \\
\text { yang ditandai } \\
\text { dengan nilai t } \\
\text { 22,40. Perbedaan } \\
\text { dalam perubahan } \\
\text { rata-rata kualitas } \\
\text { tidur sebelum dan } \\
\text { sesudah diberikan } \\
\text { relaksasi autogenik } \\
\text { menggunakan } \\
\text { aromaterapi } \\
\text { cendana pada } \\
\text { kelompok kontrol } \\
\text { dan kelompok } \\
\text { intervensi adalah } \\
6,16 \text { poin. Kualitas } \\
\text { tidur responden } \\
\text { menjadi 4-5 jam } \\
\text { per hari sehingga } \\
\text { meningkat menjadi } \\
7-8 \text { jam per hari }\end{array}$ & \\
\hline $\begin{array}{l}\text { - (Nasiri Lari et } \\
\text { al., 2020) }\end{array}$ & $\begin{array}{l}\text { Efficacy Of } \\
\text { Inhaled Lavandula } \\
\text { Angustifolia Mill. } \\
\text { Essential Oil On } \\
\text { Sleep Quality, } \\
\text { Quality Of Life And } \\
\text { Metabolic Control } \\
\text { In Patients With } \\
\text { Diabetes Mellitus } \\
\text { Type II And } \\
\text { Insomnia }\end{array}$ & 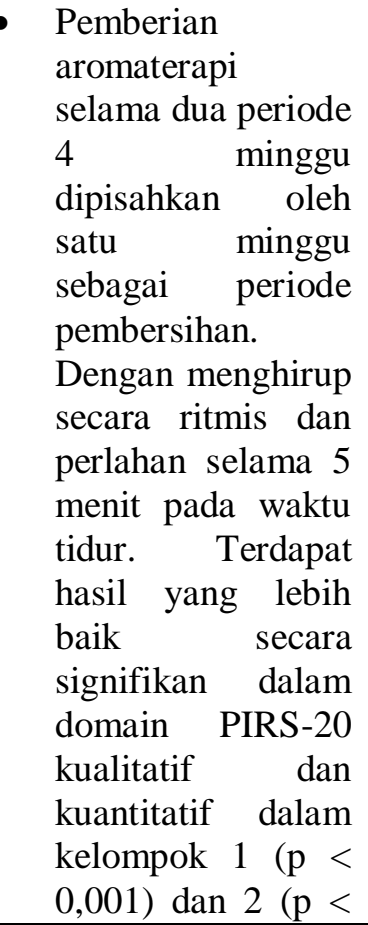 & $\begin{array}{l}\text { Terapi Aromaterapi } \\
\text { Lavender dengan } \\
\text { cara inhalasi }\end{array}$ \\
\hline
\end{tabular}




\begin{tabular}{|c|c|c|c|}
\hline & & $\begin{array}{l}\text { 0,05) } \\
\text { dibandingkan } \\
\text { dengan plasebo. } \\
\text { Tetapi tidak ada } \\
\text { perbedaan yang } \\
\text { signifikan antara } \\
\text { dua kelompok } \\
\text { mengenai kadar } \\
\text { serum gula darah } \\
\text { puasa dan hasil } \\
\text { antropometrik (p> } \\
\text { 0,05). }\end{array}$ & \\
\hline - $\underset{2019)}{(\text { Hur et al., }}$ & $\begin{array}{lr}\text { Effects } & \text { of } \\
\text { aromatherapy on } \\
\text { stress, fructosamine, } \\
\text { fatigue, and sleep } \\
\text { quality in } \\
\text { prediabetic middle- } \\
\text { aged women: A } \\
\text { randomised } \\
\text { controlled trial }\end{array}$ & 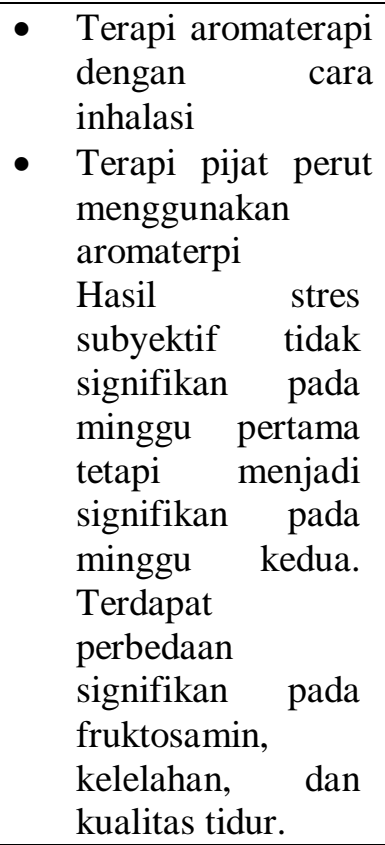 & $\begin{array}{l}\text { Terapi aromaterapi } \\
\text { dan massage terapi }\end{array}$ \\
\hline $\begin{array}{l}\text { (Meldy } \\
\text { Tursina et al., } \\
\text { 2019) }\end{array}$ & $\begin{array}{l}\text { Meningkatnya } \\
\text { Quality of Life } \\
\text { (QoL) } \\
\text { Intervensi Sengan } \\
\text { Kaki } \\
\text { Aromatherapy } \\
\text { Lavender } \\
\text { Pasien Pada } \\
\text { Melitus Tipe } 2 \text { di } \\
\text { Puskesmas } \\
\text { Rambipuji }\end{array}$ & $\begin{array}{l}\text { Peneliti memberikan } \\
\text { aromaterapi lavender } \\
\text { dan meneteskannya } \\
\text { pada bola - bola kapas } \\
\text { yang } r \text { kemudian } \\
\text { dimasukkan } r \text { pada } \\
\text { plastik klip untuk } \\
\text { membuat aromanya } \\
\text { bertahan dan diberikn } \\
\text { senam kaki } 3 \text { kali } \\
\text { secara rutin dalam } \\
\text { seminggu dan } \\
\text { aromatherapy lavender } \\
\text { setiap malam sebelum } \\
\text { tidur hasilnya Quality } \\
\text { of Life (QoL) sebelum } \\
\text { dilakukan senam kaki }\end{array}$ & $\begin{array}{l}\text { Aromaterapi } \\
\text { lavender dan senam } \\
\text { kaki }\end{array}$ \\
\hline
\end{tabular}




\begin{tabular}{|c|c|c|}
\hline & & 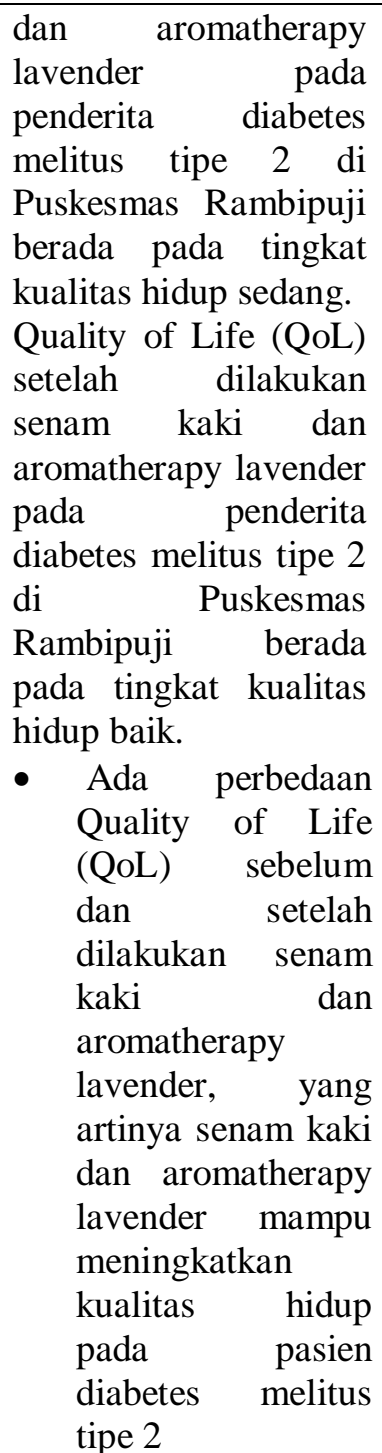 \\
\hline $\begin{array}{l}\text { - (Gok Metin et } \\
\text { al., 2017) }\end{array}$ & $\begin{array}{l}\text { Aromatherapy } \\
\text { Massage for } \\
\text { Neuropathic Pain } \\
\text { and Quality of Life } \\
\text { in Diabetic Patients }\end{array}$ & $\begin{array}{l}\text { Durasi setiap pijat } \\
30 \text { menit, dengan } \\
20 \text { menit untuk } \\
\text { kaki dan } 10 \text { menit } \\
\text { untuk tangan. } \\
\text { Intervensi dimulai } \\
\text { dnegan kaki kanan, } \\
\text { bergerak kekiri, } \\
\text { tangan kanan, dan } \\
\text { tangan kiri dengan } \\
6 \mathrm{ml} \text { minyak atsiri } \\
2 \mathrm{ml} \mathrm{digunakan} \\
\text { pada setiap kaki } \\
\text { dan } 1 \text { ml untuk } \\
\text { maisng - masing }\end{array}$ \\
\hline
\end{tabular}




\begin{tabular}{|c|c|c|}
\hline & $\begin{array}{l}\text { tangan.hasil } \\
\text { aromaterapi efektif } \\
\text { untuk mengelola } \\
\text { nyeri neuropatik } \\
\text { dan meningkatkan } \\
\text { kualitas hidup }\end{array}$ & \\
\hline $\begin{array}{ll}\text { - (Sharifi et al., } & \text { The Effect of } \\
& \text { Orange Essence } \\
& \text { Aromatherapy on } \\
& \text { Anxiety in School- } \\
& \text { Age Children with } \\
& \text { Diabetes }\end{array}$ & $\begin{array}{l}\text { Aromaterapi } \\
\text { diberikan } 3 \text { kali } \\
\text { seminggu sebelum } \\
\text { waktu tidur selama } \\
2 \quad \text { minggu. } \\
\text { Hasilnya } \\
\text { signifikan } \\
\text { dibandingkan } \\
\text { sebelum intervensi }\end{array}$ & $\begin{array}{lr}\text { Terapi } & \text { aromaterapi } \\
\text { orange } & \text { essence } \\
\text { dengan cara inhalasi }\end{array}$ \\
\hline $\begin{array}{ll}\text { - (Abdollahi \& } & \text { The effect of } \\
\text { Mobadery, } & \text { aromatherapy with } \\
\text { 2020) } & \text { bitter orange (Citrus } \\
& \text { aurantium) extract } \\
& \text { on anxiety and } \\
& \text { fatigue in type } 2 \\
& \text { diabetic patients }\end{array}$ & 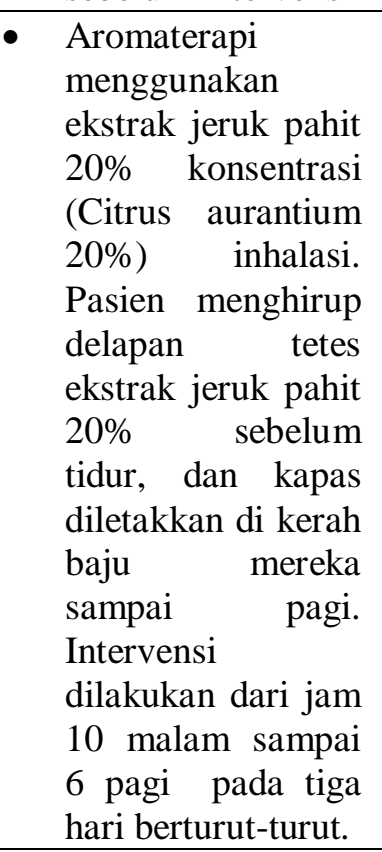 & $\begin{array}{l}\text { Terapi aromaterapi } \\
\text { bitter orange dengan } \\
\text { cara inhalasi }\end{array}$ \\
\hline $\begin{array}{l}\text { Berdasarkan Tabel } 1 \text { Hasil } \\
\text { Identifikasi terdapat tiga utama yaitu, } \\
\text { terapi aromaterapi lavender, terapi } \\
\text { aromaterapi extract bitter orange, dan } \\
\text { terapi relaksasi autogenik dengan } \\
\text { aromaterapi sandalwood yang dapat } \\
\text { digunakan dalam meningkatkan kualitas } \\
\text { tidur, kualitas hidup dan kecemasan pada } \\
\text { pasien diabetes melitus tipe } 1 \text { maupun tipe } \\
2 \text { dengan cara inhalasi maupun massage } \\
\text { dengan kombinasi senam kaki. Setelah }\end{array}$ & $\begin{array}{l}\text { menyajikan ringkas } \\
\text { artikel yang dipilih } \\
\text { literatur, penulis } n \\
\text { dari hasil ringkasar } \\
\text { dilakukan. Identifik } \\
\text { merujuk pada te } \\
\text { dengan tujuan dan } \\
\text { Adapun tema yang } \\
\text { adalah aromaterapi } \\
\text { kualitas tidur secai } \\
\text { adalah hasil tema p }\end{array}$ & $\begin{array}{l}\text { san kritis dari semua } \\
\text { sebagai materi kajian } \\
\text { nengidentifikasi tema } \\
\text { literatur yang sudah } \\
\text { asi dilakukan dengan } \\
\text { muan utama terkait } \\
\text { pertanyaan penelitian. } \\
\text { berhasil teridentifikasi } \\
\text { efektif meningkatkan } \\
\text { ra signifikan. Berikut } \\
\text { ada tabel } 2 \text {. }\end{array}$ \\
\hline
\end{tabular}


Tabel 3. Tema Penelitian

\begin{tabular}{ll}
\hline Kode Artikel & \multicolumn{1}{c}{ Temuan Hasil Penelitian } \\
\hline The Effect Of Aromatherapy & Terdapat perbedaan yang signifikan \\
On Sleep Quality In & secara statistik dalam durasi tidur, \\
Diabetes Patients With & efisiensi tidur, dan kualitas tidur \\
Restless Leg Syndrome & secara keseluruhan antara kedua \\
$=$ & kelompok $(P<0,05)$. Rata - rata \\
Artikel 1 (A1) & waktu tidur responden meningkat \\
& dari 6 jam 15 mneit menjadi 7 jam \\
& 55 menit.
\end{tabular}

Autogenic Relaxation With Aromatherapy Cendana On The Quality Sleeping In Patients Diabetes Mellitus Type 2$$
=
$$

Artikel 2 (A2)

\section{Efficacy of Inhaled}

Lavandula Angustifolia Mill

Essential Oil on Sleep

Quality, Quality Of Life and

Metabolic Control in

Patients With Diabetes

Mellitus Type 2 and

Insomnia

$=$

Artikel 3 (A3)

Effects of aromatherapy on stress, fructosamine, fatigue, and sleep quality in prediabetic middle-aged women: A randomised controlled trial
Kelompok intervensi menunjukkan bahwa semua responden mengalami peningkatan kualitas tidur setelah diberikan relaksasi autogenik menggunakan aromaterapi cendana dengan peningkatan kualitas tidur rata - rata pada kelompok kontrol 5,83 sementara nilai kelompok intervensi lebih besar yaitu 22,40. Dan rata - rata durasi tdiur responden dari 4-5 jam perhari menjadi 7-8 jam perhari.

Lavender yang diberikan secara inhalasi menghasilkan hasil yang lebih baik secara signifikan dalam domain PIRS-20 kualitatif dan kuantitatif dalam kelompok 1 ( $\mathrm{p}<$ $0,001)$ dan 2 ( $\mathrm{p}<0,05)$ dibandingkan dengan plasebo. Tetapi tidak ada perbedaan yang signifikan antara dua kelompok mengenai kadar serum gula darah puasa dan hasil antropometrik ( $p>$ $0,05)$.

Hasil stres subyektif tidak signifikan pada minggu pertama tetapi menjadi signifikan pada minggu kedua. Terdapat perbedaan signifikan pada fruktosamin, kelelahan, dan kualitas tidur

\section{Tema \\ Terapi aromaterapi lavender efektif dalam meningkatkan kualitas tidur secara signifikan}

Terapi relaksasi dengan aromaterapi cendana efektif dalam meningkatkan kualitas tidur secara signifikan

Aromaterapi lavender efektif dalam meningkatkan kualitas tidur secara signifikan

Aromaterapi lavender dan terapi massage signifkan pada fruktosamin, kelelahan dan kualitas tidur.

$$
=
$$

Artikel 4 (A4) 


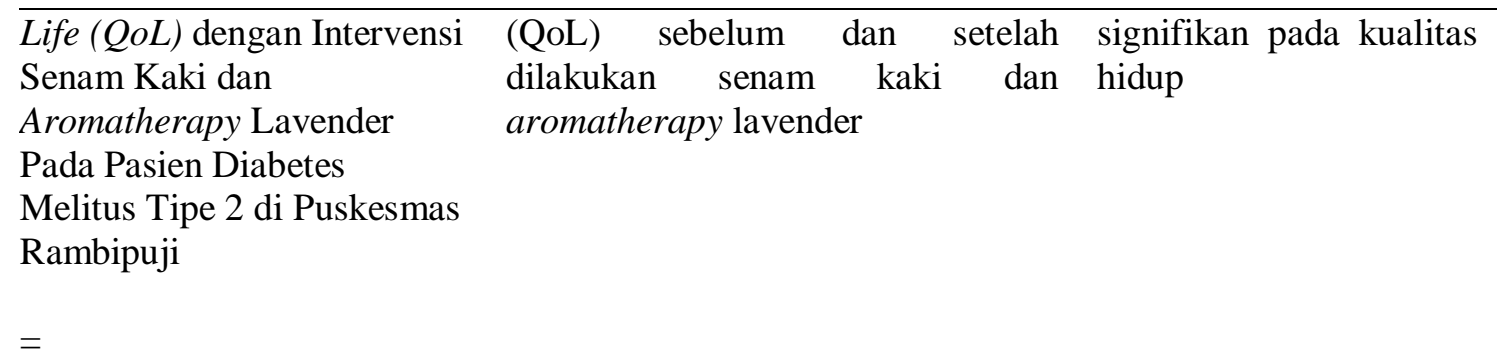

Artikel 5 (A5)

Aromatherapy Massage for Neuropathic Pain and Quality of Life in Diabetic Patients Zehra

$=$

Artikel 6 (A6)

The Effect of Orange Essence Aromatherapy on Anxiety in School-Age Children with Diabetes $=$

Artikel 7 (A7)

The effect of aromatherapy with bitter orange (Citrus aurantium) extract on anxiety and fatigue in type 2 diabetic patients

$=$

Artikel 8 (A8)

Aromaterapi mengurangi skor nyeri neuropatik dan meningkatkan kualitas hidup setelah 4 minggu intervensi

Setelah intervensi kecemasan sosial dan kecemasan umum menunjukkan perbedaan statistik yang signifikan antara tes dan kelompok kontrol. ( $\mathrm{P}<0,05)$.
Aromaterapi lavender signifikan pada skor nyeri dan kualitas hidup
Aromaterapi orange essence signifikan pada kecemasan

$$
\begin{aligned}
& \text { Penurunan tingkat kecemasan ini } \\
& \text { sebelum dan sesudah } \\
& \text { Intervensi signifikan secara statistik } \\
& (\mathrm{P}<0,001) \text {. Penurunan tingkat } \\
& \text { kelelahan sebelum dan sesudah } \\
& \text { intervensi secara statistik signifikan } \\
& (\mathrm{P}<0,014) \text {. }
\end{aligned}
$$

Aromaterapi bitter orange signifikan pada kecemasan dan kelelahan

\begin{tabular}{ll}
\hline Berdasarkan pada tabel 2 tahap & \\
pengembangan tema, tema dibagi & PEMBAHASAN \\
menjadi beberapa subtema yaitu & Diabetes melitus di definisikan \\
Aromaterapi lavender, aromaterapi & sebagai penyaki metabolik yang \\
cendana dan aromaterapi biiter orange & berlangsung kronik progresif (lama dan \\
baik dengan cara inhalasi maupun & bertambah parah) dengan tanda dan \\
massage. Pengembangan tema ini & gejala seperti kadar glukosa darah \\
didasarkan pada jenis aromaterapi yang & meningkat dan terdapat gangguan \\
mempengaruhi terjadinya perubahan & metabolisme karbohidrat, lemak dan \\
kualitas tidur, kualitas hidup, kecemasan & protein. Hal ini dapat disebebkan dar \\
dan kelelahan secara signifikan pada & berbagai faktor seperti seperti gangguan \\
pasien diabetes mellitus tipe 1 maupun & pengeluaran insulin dan sistem kerja \\
tipe 2 & insulin (Yahya, 2018). Diabetes melitus
\end{tabular}


dikaitkan dengan konsekuensi metabolik defisiensi insulin artinyajika terjadi hiperglikemia berat dan melebihi ambang ginjal untuk zat ini, dapat terjadi glikosuria kemudian glikosuria akan mengakibatkan diuresis osmotik yang meningkatkan pengeluaran urine (poliuria) dan timbul rasa haus (polidipsi). Karena glukosa hilang bersama urine, maka terjadi keseimbangan kalori negatif dan berat badan berkurang. Rasa lapar yang semakin besar (polipagia) mungkin timbul sebagai akibat kehilangan kalori. Di sisi lain, diabetes yang tidak terkontrol dapat mengurangi kualitas tidur. Gejala hiperglikemik seperti haus, lidah kering, nokturia dan gejala hipoglikemia seperti berkeringat dan takikardia dapat menyebabkan gangguan tidur pada pasien diabetes (Nasiri Lari et al., 2020). Hal ini lah yang menyebabkan terjadinya penurunan kualitas tidur terhadap pasien diabetes melitus tipe II. Hal ini sesuai dengan jurnal menurut ( $\mathrm{Yu} \&$ Chiou, 2018) yang mengatakan bahwa 50\% orang penderita diabetes memiliki kualitas tidur yang cukup buruk. Hal ini serupa dengan penelitian (Kalsum, 2015) yang mengatakan terdapat korelasi antara kualitas tidur dengan kadar glukosa darah hiperglikemia yaitu sebesar $69 \%$ pada pasien diabetes melitus tipe 2 memiliki kualitas tidur kurang baik. Definisi tidur itu sendiri adalah suatu proses fisiologis yang berputar dan bergantian, dengan periode jaga yang lebih lama. Fungsi fisiologis dan respon perilaku dipengaruhi oleh Siklus tidur bangun (Potter \& Perry, 2010). Menurut (Nashori \& Wulandari, 2017) Tidur merupakan suatu kondisi yang ditandai oleh kesadaran yang menurun, namun aktivitas didalam tubuh tetap memiliki peran dalam mengatur berbagai fungsi fisiologis, psikologis maupun spiritual manusia. Kualitas tidur seseorang dapat dipengaruhi oleh beberapa faktor diantaranya seperti usia, pengaruh obat, gaya hidup, stress emosional, lingkungan, dan tingkat kelelahan sesorang. Adapun faktor - faktor yang mempengaruhi kadar glukosa darah pada penderita diabetes melitus tipe 2 seperti makanan atau diet, olahraga atau latihan fisik, stress, istirahat atau tidur dan obat - obatan penurun kadar glukosa pada pasien diabetes melitus (Kalsum, 2015).

Gangguan tidur menjadi lebih umum, mempengaruhi fisik dan kesehatan mental serta dianggap sebagai bagian penting dari kesehatan secara keseluruhan dalam masyarakat modern kita. Gangguan tidur dapat disebabkan oleh berbagai kondisi medis, penyakit mental dan penyakit kronis seperti diabetes dan penyakit jantung. (Talih, Ajaltouni, \& Kobeissy, 2016). Selain peran gangguan tidur sebagai faktor risiko diabetes, juga disarankan sebagai alasan penting untuk kontrol glukosa darah yang buruk pada pasien diabetes. Dalam sebuah survei pada 40 pasien diabetes di Chicago, ada korelasi yang signifikan antara kualitas tidur yang buruk, gula darah yang tidak terkontrol dan resistensi insulin yang lebih tinggi (Knutson et al., 2011). Investigasi retrospektif lain pada pasien diabetes tipe 2 menunjukkan variabilitas Hemoglobin A1c yang lebih tinggi dan kadar glukosa pada pasien yang menderita insomnia dibandingkan dengan kontrol (Alshehri et al., 2018). Toleransi glukosa abnormal, resistensi insulin dan berkurangnya respon terhadap insulin terjadi karena kualitas tidur yang kurang baik dan mengalami penurunan sehingga 
menyebabkan gangguan endokrin dan metabolisme (Caple dan Grose, 2011). Penurunan sensitivitas insulin dapat terjadi akibat gangguan tidur terutama NREM selama 3 hari secara berurutan sekitar 25\% (Spiegel et al., 2009).

Pasien dengan gangguan tidur juga mengeluh tentang ketidakpuasan dengan kualitas tidur, waktu tidur dan jumlah tidur yang diterima. Gangguan tidur merupakan salah satu masalah umum pada pasien diabetes sering mengalami kesulitan tidur. Diabetes yang terkait dengan gangguan tidur adalah penyakit yang mengancam jiwa dengan meningkatnya prevalensi. RLS juga merupakan kejadian umum, lebih dari $50 \%$ pasien dengan diabetes dengan sindrom kaki gelisah memiliki kualitas tidur yang buruk. RLS adalah penyebab utama gangguan kualitas dan kuantitas tidur (Mallon, Broman, \& Hetta, 2005; Modarresnia, Golgiri, Madani, Emami, \& Tanha, 2018). Ini tidak hanya memiliki dampak besar pada kualitas tidur dan kualitas hidup, tetapi juga menimbulkan beban yang signifikan pada kesehatan dan biaya terkait kesehatan (Allen, Bharmal, \& Calloway, 2011)

(Lin et al., 2016) menyatakan bahwa rata-rata waktu kualitas tidur pada pasien diabetes adalah 7,2 jam, di mana $35,1 \%$ dari peserta memiliki durasi tidur kurang dari 7 jam. Menurut Sirdhar (2003), waktu tidur rata-rata 7,2 jam; semua peserta mengindikasikan bahwa mereka ingin tidur tambahan 1,8 jam per malam. Dari penelitian ( $\mathrm{Yu} \&$ Chiou, 2018), waktu tidur rata-rata subyek penelitian adalah 5,75 jam, yang sedikit kurang dari penelitian lain. Alasannya mungkin karena itu, populasi penelitian tidak hanya berdasarkan pada diabetes saja, dan RLS mungkin menjadi alasan bagi pasien untuk kurang tidur. Diabetes dengan kualitas tidur RLS lebih buruk daripada pasien dengan diabetes saja, dan mungkin menjadi penyebab utama gangguan tidur pada pasien ini. Para peserta memiliki berbagai tingkat kualitas tidur yang buruk dalam penelitian ( $\mathrm{Yu} \&$ Chiou, 2018).

Tidur dengan rentang waktu yang kecil dapat menyebabkan penurunan hormon serotonin, yang mengakibatkan seseorang mudah stres dan tertekan. Selain itu, emosi mudah tersulut jika tubuh mulai merasa lelah. Peningkatan kadar hormon stres, otak tidak bisa berpikir lebih baik, dan lebih mudah tertekan jika kebutuhan tidur berkurang. Sebaliknya, tubuh yang cukup tidur bisa lebih sehat, rileks dan tidak mudah stres. Stres dan kurang tidur menyebabkan kadar kortisol tinggi. Dengan hormon kortisol yang sangat tinggi, ia memicu peningkatan kadar gula darah. Tidur yang cukup dapat mengurangi kelebihan kortisol hingga 50\% (Tortora in Qoys \& Iqbal, 2014). Rata - rata problem kualitas tidur terjadi pada lansia berusia 56-65 tahun (Wijayanti et al., 2019). Terjadinya keluhan kualitas tidur seiring bertambahnya usia. Ini didukung oleh pernyataan Martono \& Pranarka (2011), bahwa di usia tua akan ada ekskresi kortisol dan GH (Growth Hormone) diikuti oleh perubahan suhu tubuh yang berfluktuasi. Melatonin, hormon yang biasanya dikeluarkan pada malam hari. Kadar hormon ini akan menurun seiring bertambahnya usia, sehingga di usia tua terjadi penurunan kualitas tidur.

Berdasarkan hasil penelitian ( $\mathrm{Yu} \&$ Chiou, 2018) dan (Wijayanti et al., 2019) menunjukkan bahwa mayoritas penderita diabetes adalah perempuan. Hasil penelitian ini konsisten dengan penelitian 
kurnia (2017) sebanyak 58,8\% terjadi pada perempuan dan $41,2 \%$ pada laki laki.

Tingkat stres dan kecemasan yang tinggi pada penderita diabetes melitus dapat mempengaruhi proses terapi yang sedang dilakukan dan menimbulkan komplikasi serius. Stres ada penderita diabetes dapat terjadi seperti diet atau pengaturan pola makan, konsumsi obat, kontrol gula darah, olahraga dan lain lain sepanjang hidupnya. Stres yang berkepanjangan dapat mempengaruhi kualitas hidup pada penderita diabetes. Kualitas hidup memiliki peran yang sangat penting selama perawatan, jika kualitas hidup rendah serta mempunyai masalah psikologis baik secara langsung maupun tidak langsung akan memperburuk gangguan metabolik(Zainuddin et al., 2015)

Salah satu faktor yang dapat mempengaruhi kondisi kesehatan seseorang adalah kualitas hidup. Suatu penyakit dapat mempengaruhi kualitas hidup seseorang, dimana jika kualitas hidup buruk akan semakin memperburuk kondisi penyakit begitupun sebaliknya jika kualitas hidup semakin baik maka kondisi penyakit akan lebih baik. Salah satu penyakit yang mempengaruhi kualitas hidup seseoarang adalah diabetes melitus walaupun dengan tanpa komplikasi(Zainuddin et al., 2015).

Kelelahan sebagai penyumbang utama yang mempengaruhi kualitas hidup buruk. Beberapa domain seperti domain fisik dan psikologis dikaitkan dengan tingkat kelelahan yang lebih tinggi. Beberapa penelitian membuktikan bahwa pada penderita penyakit kronis memiliki hubungan antara kelelahan dan kualitas hidup dan terdapat hubungan antara lima subskala pada dimensi kelelahan yaitu general, fisik, pengurangan aktifitas, pengurangan motivasi dan mental dengan dimensi fungsional dan skor total gangguan kualitas hidup (Nasekhah, 2016).

Alternatif pengobatan yang popularitasnya semakin meningkat salah satunya yaitu aromaterapi. Kata aromaterapi merupakan gabungan dari kata aroma yang berarti harum, bau wangi, sesuatu yang lembut dan kata terapi yang berimplikasi pada penanganan dokter atau orang - orang yang mempelajari ilmu kesehatan (Muchtaridi \& Moelyono, 2015). Sedangkan (Nurgiwiati, 2018)mendefinisikan aromaterapi sebagai bahan cairan tanaman yang mudah menguap dikenal sebagai minyak esensial dan senyawa aromatik lainnya yang dapat mempengaruhi jiwa, emosi dan fungsi kognitif kesehatan seseorang sebagai pengobatan alternatif.

Aromaterapi ini sendiri mampu mempengaruhi sistem olfactory yang terjadi pada sistem limbik. Ketika senyawa aroma dihirup ia siap merangsang lebih dari 50 juta reseptor sel syaraf. Reseptor yang beraksi dengan senyawa aroma pada manusia lebih dari 10.000 scents (Muchtaridi \& Moelyono, 2015). Kemudian aromaterapi dapat merangsang syaraf - syaraf pada otak dibawah kesetimbangan korteks serebral yang kemudian mampu membuat tubuh merasa lebih rileks dan tenang.

Menghirup minyak esensial adalah pendekatan tradisional yang umum diterapkan pada gangguan tidur dan Lavandula angustifolia Mill.(Lavender) adalah salah satu tanaman obat yang paling populer digunakan untuk aromaterapi (Buckle, 2014).Bau lavender digunakan secara tradisional sebagai 
ansiolitikantikonvulsan, analgesik, obat penenang dan hipnotis (Bradley et al., 2007; Coelho et al., 2018). Orang Persia, India, dan Tibet akrab dengan efek baunya pada otak dan menamakannya sebagai " the broom of the brain"(Denner, 2009). Dua bahan paling penting dalam minyak lavender adalah linalyl asetat dan linalool yang menunjukkan efek hipnotis yang signifikan (Bikmoradi et al., 2015; Karadag et al., 2017; Nikfarjam et al., 2010). Menciptakan efek - asam aminobutyric, minyak esensial Lavender menginduksi tidur terutama di amygdala dengan bekerja pada sistem lymbic. Selain itu meningkatkan kualitas tidur dengan menghasilkan efek hipnotis dan menghambat sekresi asetilkolin (Jezdic et al., 2018; Lillehei et al., 2015; Najafi et al., 2014; Nikfarjam et al., 2010).

Analisis kimia Komposisi kimia minyak esensial Lavandula (EO) diidentifikasi menggunakan spektrometri massa-kromatografi gas (GCMS).Kromatogram ion total EO digambarkan pada Gambar 1. Tabel 1 menunjukkan komposisi kimia EO dengan waktu retensi (tR), indeks retensi (RI) dan persentase area relatif dari senyawa yang diidentifikasi dalam EO. Sebanyak 28 senyawa diidentifikasi dari minyak esensial Lavandula yang mewakili 99,39\% minyak. Linalool asetat $(42,035 \%)$ dan Linalool $(31,425 \%)$ adalah senyawa utama yang diidentifikasi dalam EO (Nasiri Lari et al., 2020).

Minyak esensial Lavandula stoechas atau lavender secara signifikan mencegah peningkatan glukosa darah dan mengurangi aktivitas enzim antioksidan yang disebabkan oleh pengobatan aloxan.Perawatan minyak atsiri subakut menginduksi penurunan peroksidasi lipid dan peningkatan aktivitas enzim antioksidan (Sebai, Selmi, Rtibi, Souli, Gharbi \& Sakly, 2013).

Dalam penelitian ( $\mathrm{Yu} \&$ Chiou, 2018), 1\% minyak esensial aromaterapi lavender diteteskan pada bagian sisi kanan dan kiri bantal selama 6 minggu. Dengan rata - rata usia responden adalah 52,2 tahun $38,6 \%$ pada laki - laki dan $61,4 \%$ pada perempuan dan $61,4 \%$ pasien dengan nokturia bahwa hasil pemberian aromaterapi terhadap kualitas tidur pada minggu ke 6 setelah intervensi terdapat perbedaan signifikan sebelum dan sesudah diberikan aromaterapi lavender dengan rata - rata waktu tidur responden meningkat dari 6 jam 15 menit menjadi 7 jam 55 menit.

Menurut hasil penelitian dari (Nasiri Lari et al., 2020) kelompok intervensi diberikan aromaterapi lavender yang dihirup dengan tiga tetes minyak esensial lavender pada kain linen (dua lapisan kain linen sekitar $12 * 12 \mathrm{~cm}$ ) dan menciumnya secara ritmis dan perlahan selama 5 menit pada waktu tidur. Hasil penelitian didapatkan rata - rata responden usia 56 tahun sebanyak 31 responden $59,6 \%$ terdapat hasil yang lebih baik pada kualitas tidur secara signifikan $\mathrm{P}<0,001$ pada kelompok 1 dan $\mathrm{P}<0,05$ pada kelompok 2 . Tetapi tidak ada perbedaan yang signifkan pada kadar serum gula darah puasa dan hasil antropometrik $\mathrm{P}>0,05)$.

Penelitian yang dilakukan (Hur et al., 2019) sebanyak 31 responden dengan usia 40 - 65 tahun diberikan intervensi aromaterapi lavender dan ylang - ylang 3\% selama 2 minggu. Diberikan dengan cara inhalasi responden diminta memakai kalung yang berisi aromaterapi $3-6$ jam dengan kalung yang dirancang berjarak $20 \mathrm{~cm}$ dari hidung, dan melakukan pijat satu kali sehari sebelum tidur atau 
sebelum mandi 15 - 20 menit selama 1 minggu terdapat hasil yang signifikan pada kualitas tidur $\mathrm{P}<0.001$.

Hal ini dikarnakan minyak esensial lavender merupakan aroma minyak esensial yang populer. Minyak atsiri lavender terbuat dari tepung sari tetapi aromanya tidak manis seperti pada umumnya. Sebaliknya, bunga ini menghasilkan aroma yang segar dan keras dengan komposisi kamper. Minyak esensial ini memiliki konsistensi yang tipis dan biasanya uap disuling.Lavender berasal dari Bulgaria, Prancis, Ukraina dan Amerika Serikat.Aroma terapi lavender dapat digunakan sebagai anti bacterial, analgesic, anti konvulsan, anti jamur, anti septik dan vasodilator. Lavender dapat digunakan dengan cara inhalasi, diffusion, topical application dan ingestion (Ramadhan \& Zettira, 2017)

Selain aromaterapi lavender bahwa aromaterapi cendana juga dapat digunakan sebagai terapi terhadap kualitas tidur. Menurut hasil penelitian (Wijayanti et al., 2019) penggunaan aromaterapi cendana mampu meningkatan kualitas tidur seseorang setelah diberikan relaksasi autogenik menggunakan aromaterapi cendana. Hasil uji-t berpasangan menunjukkan bahwa kelompok kontrol dan kelompok intervensi mengalami perubahan dengan nilai $\mathrm{p}=0,00$.

Peningkatan kualitas tidur rata-rata, bagaimanapun, pada kelompok kontrol hanya ada peningkatan 5,83. Sementara itu, nilai intervensi kelompok $\mathrm{t}$ lebih besar dari 22,40. Kelompok intervensi mendapat intervensi relaksasi autogenik menggunakan aromaterapi cendana selama satu minggu, yang berarti relaksasi autogenik menggunakan aromaterapi cendana memiliki efek pada peningkatan kualitas tidur pada pasien dengan DM tipe 2.

Hal ini disebabkan karna aromaterapi memiliki efek pada tubuh kita dimana aromanya yang harum dapat menstimulasi saraf sensorik, reseptor dan akhirnya mempengaruhi organ-organ lain sehingga dapat memiliki efek yang kuat pada emosi. Aromanya juga sangat berguna untuk meditasi. Selain itu, aroma aromaterapi cendana dapat mengurangi depresi, wangi cendana dipercaya dapat mengatasi masalah insomnia dan masalah lain yang berkaitan dengan stres sehingga mampu membuat tubuh lebih rileks dan tenang.

Berdasarkan penelitian yang dilakukan (Meldy Tursina et al., 2019)salah satu terapi relaksasi yang dapat memingkatkan kesehatan fisik dan mental salah staunya adalah senam kaki dengan aromaterapi lavender.Dapat dilakukan dengan cara aromaterapi lavender diteteskan pada bola - bola kapas yang kemudian dimasukkan pada plastik klip untuk membuat aromanya bertahan selama lebih dari 1 minggu. Hasil penelitian menunjukkan bahwa sebagian besar kualitas hidup responden sebelum diberikan aromaterapi memiliki kualitas hidup sedang yaitu 13 responden $81,3 \%$ dan setelah diberikan intervensi berada pada kualitas hidup baik yaitu 14 responden $87,5 \%$ berdasarkan hasil analisa statistik yang dilakukan didapatkan hasil bahwa $\mathrm{p}$ - value sebesar 0,000 artinya ada perbedaan Quality of Life (QoL) sebelum dan sesudah diberikan aromaterapi lavender dan senam kaki

Penelitian yang dilakukan (Lari et al., 2020) kualitas hidup pada pasien diabetes melitus tipe 2 setelah diberikan aromaterapi terdapat perbedaan. Hal ini 
juga sejalan dengan penelitian yang dilakukan (Gok Metin et al., 2017) yang memadukan lima minyak atsiri yaitu rosemary, geranium, lavender, kayu putih dan chamomile dengan campuran 5\% perbandingan $1 ; 1 ; 1 ; 1 ; 1$. Pijat aromaterapi dengan campuran minyak atsiri dioleskan ke kaki pijatan dilakukan dari jari kaki ke kaki dengan teknik effleurage. Setelah selesai pijat kaki, pijat aromaterapi diberikan untuk pijat tangan sampai kesemua jari tangan menggunakan teknik effleurage dengan durasi setiap pijat 30 menit, 20 menit untuk kaki dan 10 menit untuk tangan. Hasilnya pada minggu ke 4 terdapat perbedaan skor nyeri dan kualitas hidup pasien diabetes dengan nyeri neuropati.

Efek analgesik aromaterapi dianggap terkait dengan campuran kompleks bahan kimia yang mudah menguap yang mencapai situs memori kesenangan di dalam otak, komponen analgesik tertentu dalam minyak esensial yang dapat mempengaruhi neurotransmiter dopamin dan serotonin, dan situs reseptor nadrenalin di otak, interaksi sentuhan dengan serat sensorik di kulit dan laju penyerapan minyak esensial ke dalam aliran darah yang ditingkatkan dengan pijat (Buckle, 2014). Namun, studi klinis yang meneliti efek analgesik minyak esensial yang digunakan dalam pengobatan nyeri neuropatik sangat terbatas (Motilal \& Maharaj, 2013). Rosemary (Rosmarinus officinalis), geranium (Pelargonium graveolens), dan chamomile (Chamaemelum recutita) memiliki efek analgesik, antinociceptive, anti-inflamasi, antineuralgic, dan relaksasi otot. Lavender (Lavandula angustifolia) dan eucalyptus (Eucalyptus citriodora) memiliki khasiat yang serupa, termasuk efek analgesik, pelindung saraf, antiinflamasi, dan relaksasi otot (Gok Metin et al., 2017).

Minyak esensial orange memiliki dua tipe wewangian yaitu jeruk yang manis dan pahit. Orang berasal dri Brazil, Italy dan Amerika Serikat.Minyak esensial orange di gunakan untuk anti depresan, antiseptic, anti spasmodic, circulatory, dan digestive. Minyak esensial orange dapat di aplikasikan dengan cara inhalasi, diffusion, topical application dan ingestion(Kamalifard et al., 2017).

Bitter orange atau Citrus Aurantium dari keluarga Rutaceace memiliki kandungan limonene, linalool, linalyl asetat, karotene, coumarin, flavonoid, pectin dan p-synerine.Memiliki efek penenang, menurunkan berat badan dan anti kecemasan. Flavonoid dan p-synerin memiliki efek anti depresan(Kamalifard et al., 2017).

Penelitian yang dilakukan (Sharifi et al., 2017) aromaterapi orange essence diberikan 3 kali seminggu (Senin, Rabu dan Sabtu) sebelum tidur selama 2 minggu dengan jarak $5 \mathrm{~cm}$ dari hidung pada pasien diabetes tipe 1 setelah diberikan intervensi terdapat perbedaan yang signifikan $\mathrm{P}<0,05$ pada kecemasan sosial dan kecemasan umum.

Hal ini sejalan dengan penelitian yang dilakukan (Abdollahi \& Mobadery, 2020) sebanyak 30 responden yang diberikan intervensi ekstrak jeruk pahit $20 \%$ diberikan secara inhalasi pasien menghirup 8 tetes ekstrak jeruk pahit $20 \%$ pada kapas diletakkan dikerah baju mereka sebelum tidur. Intervensi diberikan dari jam 10 malam sampai jam 6 pagi selama tiga hari berturut - turut mengalami penurunan tingkat kecemasan sebelum dan sesudah intervensi 
signifikan secara statistik $\mathrm{P}<0,001$ dan mengalami penurunan tingkat kelelahan sebelum dan sesudah intervensi secara statistik signifikan $\mathrm{P}<0,014$.

Dari kedelapan artikel yang sudah dianalisis terdapat 3 jenis aromaterapi yang dapat digunakan untuk kualitas tidur, kualitas hidup, kecemasan dan kelelahan pada pasien diabetes melitus tipe 1 dan 2 yaitu aromaterapi lavender, aromaterapi bitter orange/ekstrak jeruk pahit dan aromaterapi cendana/sandalwood.

Pengukuran kualitas tidur pada pasien diabetes mellitus tipe 2 setelah mendapatkan terapi aromaterapi dalam kajian literatur ini dibahas dalam delapan artikel penelitian. Metode penelitian yang digunakan dari artikel - artikel penelitian yang dianalisis adalah experimental study, quasy experimental study dan randomized controlled clinical trial. Setelah melakukan analisis dengan pendekatan sederhana penulis menemukan tiga dari lima artikel penelitian yaitu aromaterapi lavender, cendana, dan bitter orange efektif dalam meningkatkan kualitas tidur, kualitas hidup, kecemasan dan kelelahan pada pasien diabetes melitus tipe 1 dan 2 secara signifikan.

Berdasarkan lima artikel yang menggunakan aromaterapi lavender yaitu penelitian dari (Gok Metin et al., 2017; Hur et al., 2019; Meldy Tursina et al., 2019; Nasiri Lari et al., 2020; Yu \& Chiou, 2018) yang menerapkan aromaterapi dengan cara inhalasi tetapi dengan cara yang berbeda. (Yu \& Chiou, 2018) minyak esensial aromaterapi lavender diteteskan pada bagian sisi kanan dan kiri bantal selama 6 minggu, adapun penelitian yang dilakukan (Nasiri Lari et al., 2020) aromaterapi lavender diberikan secara inhalasi selama 4 minggu menjadi 2 periode dengan interval 1 minggu. Sedangkan, aromaterapi bitter orange atau ekstrak jeruk pahit yang dilakukan (Abdollahi \& Mobadery, 2020; Sharifi et al., 2017) aromaterapi diberikan secara inhalasi dengan 8 tetes bitter orange $20 \%$ selama tiga malam berturut - turut. Adapun penelitian yang dilakukan (Wijayanti et al., 2019) menggunakan aromaterapi cendana atau sandalwood diberikan secara inhalasi selama 1 minggu.

\section{KESIMPULAN DAN SARAN}

Hasil dari kajian literatur ini menjawab pertanyaan dari penelitian bahwa aromaterapi lavender, bitter orange dan cendana/sandalwood cukup signifikan mempengaruhi perubahan kualitas tidur, kualitas hidup, kecemasan dan kelelahan pada pasien diabetes melitus tipe 1 dan 2. Dari kedelapan artikel Terdapat lima artikel efektif menggunakan aromaterapi lavender intervensi yang diberikan selama 4-6 minggu. Lalu satu artikel efektif menggunakan aromaterapi cendana selama 1 minggu dan dua artikel efektif dengan pemberian aromaterapi bitter orange selama tiga malam berturut turut. Maka, dapat disimpulkan bahwa aromaterapi efektif terhadap kualitas tidur, kualitas hidup, kecemasan dan kelelahan pada pasien diabetes melitus tipe 1 dan 2 .

Oleh karena itu, penggunaan aromaterapi dapat direkomendasikan sebagai intervensi non farmakologi pada pasien diabetes melitus tipe 1 ataupun tipe 2. Bagi divisi keperawatan intervensi aromaterapi dapat digunakan sebagai terapi nonfarmakologi untuk kualitas tidur, kualitas hidup, kecemasan dan 
kelelahan pada pasien diabetes melitus tipe 1 dan 2. Bagi mahasiswa/i keperawatan hasil kajian literatur ini dapat menjadi bahan dalam proses belajar dan mengajar. Selain itu, hasil kajian literatur ini akan menjadi acuan bagi mahasiswa/i dalam melakukan penelitian tentang pengaruh aromaterapi terhadap kualitas tidur, kualitas hidup, kecemasan dan kelelahan pada pasien diabetes melitus tipe 1 dan 2 di waktu mendatang. Bagi peneliti selanjutnya hasil kajian literatur ini diharapkan dapat menjadi sumber untuk melakukan penelitian selanjutnya mengenai topik pengaruh aromaterapi pada pasien diabetes mellitus.

\section{DAFTAR RUJUKAN}

Abdollahi, F., \& Mobadery, T. (2020). The effect of aromatherapy with bitter orange (Citrus aurantium) extract on anxiety and fatigue in type 2 diabetic patients. Advances in Integrative Medicine, 7(1), 3-7. https://doi.org/10.1016/j.aimed.201 9.01 .002

Atlas, I. D. F. D. (2019). Idf diabetes atlas.

Aveyard, H. (2014). Doing a Literature Review in Health and Social Care: A Practical Guide (3rd ed.). Maidenhead: McGraw-Hill Open University Press.

Barakat, S., Abujbara, M., Banimustafa, R., Batieha, A., \& Ajlouni, K. (2019).Sleep Quality in Patients With Type 2 Diabetes Mellitus. Journal of Clinical Medicine Research,11(4),261-266. https:/doi.org/1014740/jocmr2947w
Barker, J. (n.d.). Basic Search Tips and Advance Boolen Explained: Teaching Library.

Care, P. C. (2017). Comprehensive medical evaluation and assessment of comorbidities. Diabetes Care, 40(January), $\mathrm{S} 25-\mathrm{S} 32$. https://doi.org/10.2337/dc17-S006

Gok Metin, Z., Arikan Donmez, A., Izgu, N., Ozdemir, L., \& Arslan, I. E. (2017). Aromatherapy Massage for Neuropathic Pain and Quality of Life in Diabetic Patients. Journal of Nursing Scholarship, 49(4), 379388.https://doi.org/10.1111/jnu.123 00

Hudatul Umam, M., Solehati, T., \& Purnama, D. (2020). Gambaran Kualitas Hidup Pasien Dengan Diabetes Melitus Di Puskesmas Wanaraja. Jurnal Kesehatan Kusuma Husada, 70-80. https://doi.org/10.34035/jk.v11i1.4 19

Hur, M.-H., Hong, J. H., \& Yeo, S. (2019). Effects of aromatherapy on stress, fructosamine, fatigue, and sleep quality in prediabetic middleaged women: A randomised controlled trial. European Journal of Integrative Medicine, 31, 100978.https://doi.org/10.1016/J.E UJIM.2019.100978

Kalsum, U. (2015). Hubungan Kualitas Tidur Dengan Kadar Glukosa Darah Pada Pasien Diabetes Melitus Tipe 2 Di Rumah Sakit Islam Cempaka Putih Jakarta. 5(1), 233-242. 
Kamalifard, M., Khalili, A. F., Namadian, M., Herizchi, S., \& Ranjbar, Y. (2017). Comparison of the effect of lavender and bitter orange on depression in menopausal women: A triple-blind randomized controlled trial. International Journal of Women's Health and Reproduction Sciences, 5(3), 224-230. https://doi.org/10.15296/ijwhr.2017 .40

Khandelwai, D., Dutta, D., Chittawar, S., \& Kaira, S. (2017). Sleep Disorders in Type 2 Diabetes. Indian Journal of Endocrinology and Metabolism, 21(5), 758-761.

Lari, Z. N., Hajimonfarednejadab, M., Riasatian, Maryamsadat Abolhassanzadeh, Zohreh Irajie, A., Vojoud, M., Heydari, M., \& Shams, M. (2020). Efficacy Of Inhaled Lavandula Angustifolia Mill. Essential Oil On Sleep Quality, Quality Of Life And Metabolic Control In Patients With Diabetes Mellitus Type II And Insomnia. Journal of Ethnopharmacology, 251. Retrieved from https://doi.org/10.1016/j.jep.2020.1 12560

Lin, C. L., Tsai, Y. H., \& Yeh, M. C. (2016). Associations between sleep duration and type 2 diabetes in Taiwanese adults: A populationbased study. Journal of the Formosan Medical Association, 115(9), 779-785. https://doi.org/10.1016/j.jfma.2016. 01.013
Meldy Tursina, H., Purwaningrum, Y., \& Anggita Febrianti, E. (2019). Meningkatnya Quality of Life (QoL) dengan Intervensi Senam Kaki dan Aromatherapy Lavender Pada Pasien Diabetes Melitus Tipe 2 di Puskesmas Rambipuji. Jurnal Kesehatan Dr. Soebandi, 7(1), 4250.

https://doi.org/10.36858/jkds.v7i1.1 40

Moher, D., Liberati, A., Tetzlaff, J., Altman, D. G., Altman, D., Antes, G., ... Tugwell, P. (2009). Preferred reporting items for systematic reviews and metaanalyses: The PRISMA statement. PLoS Medicine, 6(7). https://doi.org/10.1371/journal.pme d.1000097

Muchtaridi, \& Moelyono. (2015). Aroma Terapi; Tinjauan Aspek Kimia Medisinal. Yogyakarta: Graha Ilmu.

Nasekhah, A. D. (2016). Hubungan Kelelahan Dengan Kualitas Hidup Penderita Diabetes Melitus Tipe 2 Di Persadia.

Nashori, F., \& Wulandari, E. D. (2017). Psikologi Tidur: Dari Kualitas Tidur Hingga Insomnia. Yogyakarta: Universitas Islam Indonesia.

Nasiri Lari, Z., Hajimonfarednejad, M., Riasatian, M., Abolhassanzadeh, Z., Iraji, A., Vojoud, M., ... Shams, M. (2020). Efficacy of inhaled Lavandula angustifolia Mill. 
Essential oil on sleep quality, quality of life and metabolic control in patients with diabetes mellitus type II and insomnia. Journal of Ethnopharmacology, 251, 112560. https://doi.org/10.1016/J.JEP.2020. 112560

Nurgiwiati, E. (2018). Terapi Alternatif \& Komplementer Dalam Bidang Keperawatan (1st ed.). Bogor: In Media.

Potter, P. A., \& Perry, A. G. (2010). Fundamental Keperawatan (7th ed.). SINGAPORE: Elsevier Ltd.

Ramadhan, M. R., \& Zettira, O. Z. (2017). Aromaterapi Bunga Lavender ( Lavandula angustifolia ) dalam Menurunkan Risiko Insomnia Lavender Flower ( Lavandula angustifolia ) Aromatherapy in Lowering the Risk of Insomnia. 6, 60-63.

Riskesdas, K. (2018). Hasil Utama Riset Kesehata Dasar (RISKESDAS). Journal of Physics A: Mathematical and Theoretical, 44(8), 1-200. https://doi.org/10.1088/17518113/44/8/085201

Septimar, Z. M., Priatna, H., \& Tomi, S. Y. (2019). Effect of Benson's Relaxation Techniques On Blood Glucose Levels In Patients With Diabetes Mellitus (P. 188). P. 188.

Sharifi, A., Motaghi, M., Borji, M., \& Moradi, M. (2017). The effect of orange essence aromatherapy on anxiety in school-age children with diabetes. Biomedical and
Pharmacology Journal, 10(1), 159164. https://doi.org/10.13005/bpj/1093

Suresh, S. (2014). Nursing Research and Statistics 2nd Edition (2nd ed.). Elsevier India.

Syaodih, N. (2009). Metode Penelitian Pendidikan. Bandung: PT Remaja Rosdakarya.

Tomasic, D. (2011). Health Sciences Literature Review Made Easy: The Matrix Method, 3rd Edition. American Journal of Health-System Pharmacy, 68(23), 2302-2302. https://doi.org/10.1093/ajhp/68.23.2 $302 \mathrm{a}$

Wijayanti, L., Wardani, E. M., \& Bistara, D. N. (2019). Autogenic Relaxation with Aromaterapy Cendana on The Quality of Sleeping in Patients Diabetes Mellitus Type II. Journal Of Nursing Practice. https://doi.org/10.30994/jnp.v3i1.6 8

Yahya, N. (2018). Hidup Sehat Dengan Diabetes. Jln. Dr. Supomo: PT Tiga Serangkai.

Yu, P.-J., \& Chiou, A.-F. (2018). The Effects of Aromatherapy on Sleep Quality in Diabetes Patients with Restless Leg Syndrome in Taiwan. European Scientific Journal, ESJ, 14(30), 371. https://doi.org/10.19044/esj.2018.v 14n30p371

Zainuddin, M., Utomo, W., \& Herlina. (2015). Hubungan Stres Dengan 
Kualitas Hidup Penderita Diabetes Mellitus Tipe 2 Mhd. Zainuddin 1 , Wasisto Utomo 2 , Herlina 3. 2(1), 890-898. 